\title{
Ecocide Is Genocide: Decolonizing the Definition of Genocide
}

Lauren J. Eichler

Old Dominion University

Follow this and additional works at: https://digitalcommons.usf.edu/gsp

\section{Recommended Citation}

Eichler, Lauren J. (2020) "Ecocide Is Genocide: Decolonizing the Definition of Genocide," Genocide Studies and Prevention: An International Journal: Vol. 14: Iss. 2: 104-121.

DOI:

https://doi.org/10.5038/1911-9933.14.2.1720

Available at: https://digitalcommons.usf.edu/gsp/vol14/iss2/9

This Articles is brought to you for free and open access by the Open Access Journals at Digital Commons @ University of South Florida. It has been accepted for inclusion in Genocide Studies and Prevention: An International Journal by an authorized editor of Digital Commons @ University of South Florida. For more information, please contact digitalcommons@usf.edu. 


\section{Ecocide Is Genocide: Decolonizing the Definition of Genocide}

\section{Acknowledgements}

As a non-Indigenous person of European descent who wrote this article while living on the traditional lands of the Kalapuya and Chesapeke peoples, I would like to express my gratitude to the Indigenous scholars and communities who have shared their philosophies and stories, which has made this critique possible. I hope this research contributes to creating a more equitable pathway for Indigenous peoples to achieve justice for the violence they have experienced and are experiencing. I would also like to thank the editors for their support and the reviewers for their thoughtful feedback on this article. 


\title{
Ecocide Is Genocide: Decolonizing the Definition of Genocide
}

\author{
Lauren J. Eichler \\ Old Dominion University \\ Norfolk, Virginia, USA
}

\section{Introduction}

In 1492, European explorers arrived in the Americas, bringing devastating changes to the land, ecosystems, and lives of the Indigenous peoples. Some of these changes were wrought unintentionally, such as the diseases, rats, and invasive plant species that came with the settlers. Other changes, like the clear-cutting of forests to make way for farms and homesteads, the hunting of game animals to near extinction, and the removing of Indigenous peoples from their traditional lands, were more deliberate. For the Indigenous peoples, these changes had long term ramifications for the vitality of their cultures, the effects of which are still being experienced today. According to the worldviews of many Native American cultures, the destruction brought upon the land, water, and nonhuman beings of the Americas was an act of violence against their communities. I argue that this violence should be considered an act of genocide and that the study of genocide and our current responses to it are still largely colonial and anthropocentric.

In this article, I demonstrate how the destruction of nonhuman animals, land, water, and other nonhuman beings constitute forms of genocide according to Indigenous metaphysics. ${ }^{1}$ In environmental studies and genocide studies, the destruction of nonhuman beings and nature is typically treated as a separate, but related phenomenon-ecocide, the destruction of nonhuman nature. In this article, I follow in the footsteps of Native American and First Nations scholars like Donald Grinde, Winona LaDuke, Tasha Hubbard, and Laurelyn Whitt to argue from an Indigenous perspective on nonhuman personhood that ecocide and the genocide of Indigenous peoples are inextricably linked and are even constitutive of the same act. Recognizing that ecocide is a form of genocide challenges the anthropocentricism implicit in the current definition of genocide and expands the concept of genocide without significantly altering its official legal definition. I argue that if justice is to be achieved for Indigenous peoples through the United Nations' ability to prosecute genocide, then the definition of genocide needs to - at minimum-include ecocide as a recognized act.

\section{Cultural Genocide, Social Death, and Ecocide}

One of the primary shortcomings of the human rights approach to responding to genocidal violence is that the focus of humanitarian efforts becomes based almost entirely on the wellbeing of individual humans rather than with concern for the natural world that sustains them. The Universal Declaration of Human Rights (UDHR) does not mention the environment, the natural world, or creatures other than humans, even though human life depends on nonhuman nature for sustenance and cultural development. Both the definition of genocide-which accounts only for human groups - and the UDHR exhibit such shortcomings, writing nonhuman animals and other beings out of the ethical and political equation when it comes to atrocities. Yet, such a limited definition of genocide and human wellbeing has not been the only way of interpreting genocide and genocidal violence. Raphaël Lemkin defined genocide in a significantly different way than

${ }^{1}$ Two points of note-first, in this article, I will focus primarily on the troubles faced by and the philosophies of Indigenous communities located in North America. However, the philosophies of other Indigenous groups, including the Maori and those located in South America and India, overlap in significant ways and could also be applied to the argument I make. Second, I use various terms to refer to the Indigenous peoples of North America including Native Americans, Indigenous peoples, Natives, First Nations, and American Indians. When possible, I try to use specific tribal/national affiliations, but when I am discussing philosophical positions and experiences held by many tribes in common, I use umbrella terms like those listed above. First Nations refers specifically to Indigenous communities within the borders of Canada while American Indians refer to Indigenous peoples living within the borders of the contiguous US and Alaska. I typically use the term Native Americans when I am referring broadly to Indigenous peoples who live within Canada and the US. Indigenous peoples is likewise used in a similar way to indicate Native peoples and communities within the US generally speaking and at times to be inclusive of Indigenous peoples elsewhere in the world. Though the term "indigenous" is a contested concept, for the purposes of this article and my focus on the North American context, by "Indigenous peoples" I mean communities and peoples who were residing in North America prior to the continent's colonization by Europeans. 
the definition eventually adopted by the UN. According to Lemkin, genocide does not necessarily entail the physical destruction of a national or ethnic group. Rather, genocide signifies,

a coordinated plan of different actions aiming at the destruction of essential foundations of the life of national groups, with the aim of annihilating the groups themselves. The objects of such a plan would be the disintegration of the political and social institutions, of culture, language, national feelings, religion, and the economic existence of national groups, and the destruction of the personal security, liberty, health, dignity, and even the lives of the individuals belonging to such groups. ${ }^{2}$

Whereas the UN definition mainly restricts genocide to acts carried out against the bodies and individuals of the targeted human group, Lemkin's definition accounts for a much broader understanding of what constitutes group destruction. ${ }^{3}$ In addition to mass murder, preventing births, and physical destruction, Lemkin also includes the dissolution of political parties, colonization, abolition of local law, censorship, restrictions on language, withholding food and medicine, moral debasement, and crippling economic development. Unlike the acts listed in the UN definition, which predominantly describe harms that directly affect the physical body of the group members, these acts are indirect harms that compromise quality of life and the ability of a group to carry on as a group. The acts that Lemkin lists destroy a group not by taking lives per se but by forcefully supplanting one group's way of being in the world - the principles, institutions, and values that make that group distinct from other human groups - with the principles, institutions, and values held by another group.

This broader conception aligns with more recent conversations about genocide. Claudia Card, for example, argues that what distinguishes genocide from other crimes against humanity is its role in bringing about social death. ${ }^{4}$ According to Card, a social group is not just a collection of individuals but a set of relationships. ${ }^{5}$ These relationships contribute to the social vitality of a group and are constituted by social, institutional, political, and moral practices. ${ }^{6}$ Social death involves the breakdown or eradication of these relationships so that what made life as a group meaningful no longer exists. Social vitality not only applies to living members of the group, but also connects members of the group through history and time. ${ }^{7}$ It is intergenerational. Genocide, both physical and cultural, inhibits the flourishing, growth, and organic development of these relationships. Though social death can be understood within the terms of the UN definition, Lemkin's definition, which directs attention to the destruction of cultural relationships, makes this particular harm more evident.

Recently, genocide scholars have demonstrated renewed interest in Lemkin's writings. Frustrated by the limitations of the UN definition, researchers like Dirk Moses, Damien Short, and Jürgen Zimmerer see Lemkin's research as one way of conceptualizing problems related to genocide that have been under-theorized or overlooked, especially regarding colonization. ${ }^{8}$ These authors note that the UN's narrow definition does a great disservice to colonized Indigenous peoples who

\footnotetext{
${ }^{3}$ United Nations, General Assembly Resolution 260, Convention on the Prevention and Punishment of the Crimes of Genocide, December 9, 1948 (UN Doc. A/RES/260(III)), accessed July 16, 2020, https://www.un.org/en/genocideprevention/ documents/atrocity-crimes/Doc.1 Convention $\% 20$ on $\% 20$ the $\% 20$ Prevention $\% 20$ and $\% 20$ Punishment $\% 20$ of $\% 20$ the $\% 20$ Crime\%20of\%20Genocide.pdf

${ }^{4}$ Claudia Card, "Genocide and Social Death," in Genocide's Aftermath: Responsibility and Repair, ed. Claudia Card and Armen T. Marsoobian (Malden: Blackwell Publishing, 2007), 10-26.

${ }^{5}$ Ibid., 10-11.

${ }^{6}$ Ibid., 16.

${ }^{7}$ Ibid., 20.

${ }^{8}$ Dirk A. Moses, "Empire, Colony, Genocide: Keywords and the Philosophy of History," in Empire, Colony, Genocide: Conquest, Occupation, and Subaltern Resistance in World History, ed. A. Dirk Moses (New York: Berghahn Books, 2008), 3-54; Damien Short, Redefining Genocide: Settler Colonialism, Social Death, and Ecocide (London: Zed Books, 2016); Jürgen Zimmerer, "Colonialism and the Holocaust: Towards an Archeology of Genocide," in Genocide and Settler Society: Frontier Violence and Stolen Indigenous Children in Australian History, ed. A. Dirk Moses (New York: Berghahn Books 2004), 49-76.
} 
were not always killed in the process of colonization but whose group life was forcibly altered and destroyed through the efforts of colonizers. Even acts that were considered "humanitarian" or "humanizing" such as residential schools, reservations, and other efforts at assimilating Native peoples into the new dominant culture often brought about social and cultural death by depriving people of maintaining traditions, language, and relationships not only with one another but also with the land and other elements of nonhuman nature around them.

Though there is growing interest in the link between colonization and genocide, the majority of genocide literature, which debates definitions and legal action, perpetuate (often unintentionally) the erasure of the plight of Indigenous peoples as an act of genocide. The experiences of colonized Indigenous peoples are treated as categorically different from genocide. For example, in Native America and the Question of Genocide, Alex Alvarez argues that the term genocide is overused when discussing the harms experienced by the Indigenous peoples of North America. Many of these assertions of genocide, he says, "seem to be based more on a general sense of outrage and horror than on any clear and rigorous understanding about what is or is not genocide." ${ }^{9}$ Though he approaches the claims of genocide in North America with some skepticism, Alvarez does not say genocide did not occur. Rather, "care needs to be taken when applying this label to specific historical events." ${ }^{10}$ Following a review of various episodes of violence perpetrated against Native Americans, Alvarez concludes that the Trail of Tears, though horrific, was not genocide, while the residential school system was a form of cultural genocide, ${ }^{11}$ and the massacres of Californian Indians were definitely genocide. Native American scholar Joseph P. Gone of the Gros Ventre Nation makes a similar argument in his article "Colonial Genocide and Historical Trauma in North America," but he goes a step further than Alvarez in restricting the definition of genocide. Gone argues that for the sake of conceptual clarity, genocide should refer only to instances of violence that involve mass murder. He argues that there are already a variety of terms to describe various acts of violence including ethnic cleansing, colonization, massacres, and human rights violations: "Thus, what seems to be distinctive about the term genocide is its reference to the "crime of all crimes,' namely, group-based mass murder." ${ }^{12}$ Given this definition, Gone holds that much of the violence that occurred against Native Americans through colonization is not genocide even though intermittent genocides did occur as colonization proceeded. He specifically calls into question the value of lumping Indian killers, buffalo hunters, and residential school teachers together as perpetrators of genocide. ${ }^{13}$ In other words, Gone claims that genocide was not "at all typical or representative, of the European project of colonization, or that colonization can be casually equated with genocide." ${ }^{14}$ For both authors, the goal of making these distinctions is to ensure that the power of the word genocide does not become diluted.

Alvarez and Gone's reasons for so narrowly defining genocide might be beneficial for bringing about conceptual clarity and might reflect a consideration for the legal standing of the definition, but mass killing hardly exhausts the methods that can be used to destroy a group. Lemkin's definition, which accounts for the destruction of language, religion, and other cultural institutions, provides a more nuanced account of what happened and is still happening to Indigenous peoples in North America and around the world. Though Lemkin did not specifically talk about the destruction of nature, the environment, or ecosystems in his definition of genocide, his definition leaves room for the inclusion of this issue. This is particularly relevant for Indigenous peoples whose physical and cultural destruction coincided with their removal from their land, the decimation of various

\footnotetext{
${ }^{9}$ Alex Alvarez, Native America and the Question of Genocide (Lanham: Rowman \& Littlefield, 2014), 3.

${ }^{10}$ Ibid., 4.

${ }^{11}$ Notice here that Alvarez uses the term "cultural" to modify "genocide," implying that residential schools are not examples of outright genocide, a term which he reserves for incidents that typically involve mass murder. For more on his usage of the term "cultural genocide," see Alvarez Native America and the Question of Genocide, 156-157.

${ }^{12}$ Joseph P. Gone, "Colonial Genocide and Historical Trauma in Native North America: Complicating Contemporary Attributions," in Colonial Genocide in Indigenous North America, ed. Andrew Woolford et al. (Durham: Duke University Press, 2014), 279.

${ }^{13}$ Ibid., 285.

${ }^{14}$ Ibid., 284.
} 
nonhuman animal species including beaver and bison, and alterations to the landscape including the damming of rivers, deforestation, and the introduction of new pollutants. Because many Indigenous cultures lived in close proximity to the other-than-human world around them and often viewed nonhuman beings as community members, the destruction of these relationships would have constituted a type of social death.

The majority of genocide literature does not seriously or thoroughly analyze the connection between genocide and the destruction of nonhuman nature, otherwise known as ecocide. In this respect, most genocide and human rights scholarship remains anthropocentric, such that only the destruction of and the dignity of human life is considered to be of consequence. The term "ecocide" was coined in 1970 by a group of scientists to describe the devastation being wrought to the land in Vietnam as a result of chemical weapons like Agent Orange. Lawyer and activist Polly Higgins later defined ecocide as "extensive damage to, destruction of or loss of ecosystem(s) of a given territory, whether by human agency or by other causes, to such an extent that peaceful enjoyment by the inhabitants of that territory has been severely diminished." ${ }^{15}$ Because "ecocide" is still a relatively under-theorized subject, the term covers a wide array of acts and harms. Higgins' definition of ecocide does not stipulate intent like the UN definition of genocide does. This means that humans may commit ecocide unintentionally or as a means to a different end as in the case of businesses that do not intentionally set out to destroy land, forests, or water, but do so negligently or in pursuit of some other goal. Higgins distinguishes between two forms of ecocide: non-ascertainable and ascertainable. The former has no discernible human cause, while the latter does. ${ }^{16}$ For example one type of non-ascertainable ecocide is extreme weather events related to climate change. These are not directly due to human intent; rather, they are the byproduct of human activities in the world. For the most part, however, the term is commonly used to describe perceivable harms done by humans to nonhuman beings and the planet with the effect of inhibiting the flourishing of human life. As Arthur W. Galston argued in his proposal for an international agreement on banning ecocide, "[i]t seems to me that willful and permanent destruction of environment in which a people can live in a manner of their own choosing ought similarly to be considered a crime against humanity, to be designated by the term ecocide."17 Thus, examples of ecocide are quite varied, including everything from the mass death of bees due to the overuse of pesticides to the clear-cutting of the Amazon Rainforest for the purposes of creating more farmland to climate change to the poaching of rare species to be sold on the black market as medicine, pets, or delicacies.

Though the concept of ecocide has gained traction among environmentalists and advocates for Indigenous rights, ecocide is not considered a crime on the international stage. Only ten countries have adopted laws criminalizing ecocide. ${ }^{18}$ Even though the inclusion of ecocide as an international crime has been debated at the UN various times between 1973 and 2010, culminating with a proposal to amend the Rome Statute of the Criminal Court to include ecocide as the fifth Crime against Peace, each effort to incorporate it failed. ${ }^{19}$ However, as the threats of anthropogenic climate change become increasingly real, there has been a resurgence of interest in the connection between ecocide and genocide. As Higgens points out, "ecocide leads to resource depletion, and where there is escalation of resource depletion, war comes chasing close behind." 20 And often with war comes a surge of crimes against humanity like genocide.

In Ecocide of Native America, Donald Grinde of the Yamasee tribe and Bruce E. Johansen link ecocide with the genocide of Native Americans and other indigenous peoples. By examining the testimonies of Native People impacted by a variety of environmental disasters that followed

\footnotetext{
${ }^{15}$ Polly Higgins, Eradicating Ecocide: Laws and Governance to Prevent the Destruction of Our Planet (London: ShepheardWalwyn LTD, 2010), 63.

${ }^{16}$ Ibid.

${ }^{17}$ Quoted in Short, Redefining Genocide, 40.

${ }^{18}$ These include the Republic of Belarus, Georgia, the Republic of Kazakhstan, the Kyrgyz Republic, the Republic of Armenia, the Republic of Moldova, the Russian Federation, the Republic of Tajikistan, Ukraine, and the Socialist Republic of Vietnam.

${ }^{19}$ Higgins, Eradicating Ecocide, 68-70.

${ }^{20}$ Ibid., 62.
} 
colonization including uranium mining, depletion of fisheries, and destruction of plains for ranching, the authors demonstrate how these practices have interfered with traditional indigenous methods of engaging with the nonhuman world and the devastating impact this has had on the future of those communities in physical, spiritual, and cultural ways. According to the testimony of Jewell Praying Wolf James of the Lummi Tribe, the destruction of land, water, and nonhuman life has been central to this experience of genocide.

At one time our plains, plateaus, and ancient forests were respected and not considered a wilderness. The skies were darkened with migrating fowl. The plains were blanketed with massive herds of buffalo. Our mountains teemed with elk, deer, bear, beaver, and other furbearing animals. All the rivers were full of salmon and fish-so much that you could walk across their backs to get to the other side. The plants and trees were medicines or food for us. We knew neither hunger nor disease until contact came in 1492, then our holocaust began and that of the plants, animals, and environment. ${ }^{21}$

Though Grinde and Johansen link ecocide and genocide, their focus is primarily on ecocide and less on how this connects to the problem of genocide more generally. In Redefining Genocide, sociologist Damien Short provides some of this theoretical groundwork by taking a closer look at what he deems the "genocide-ecocide nexus." Drawing on Lemkin's definition of genocide that characterizes genocide as the destruction of a group's culture as well as physical life, Short argues that ecocide has been used in the modern era to destroy Indigenous group life. For Short, ecocide is a method of genocide if "such destruction results in conditions of life that fundamentally threaten a social group's cultural and/or physical existence." ${ }^{22}$ According to Short, humans are "ecologically embedded beings." ${ }^{23}$ As such, wrecking the ecosystems in which humans persist would ultimately lead to the destruction of human lives and cultures. Through various case studies he shows how settler colonists put profits and resource extraction ahead of the lives and livelihoods of Indigenous groups who shared and continue to share the territory. Exploitation of land and resources for political and economic gain on the part of the state and businesses becomes a justification for ethnic cleansing, extermination, and forced removal of Indigenous groups.

For example, in one case study Short looks at the effects of Canada's Athabasca tar sands project on nearby First Nations communities. Short reports that in the name of energy security, the US and Canada have pursued opportunities to extract oil and other resources using risky and especially environmentally destructive technologies. The tar sands project in Alberta, Canada involves extracting bitumen, a viscous and dense form of petroleum, through techniques such as strip mining and fracking. The tar sands site, which is as large as the state of Florida, consists of mined pits, pools of oil, and rivers of water that have been redirected from all available nearby sources. The land has been stripped of wildlife, trees, and topsoil. Runoff from the mining procedures contaminates rivers on the level of major oil spills on a regular basis. These lands, which had traditionally belonged to the Cree, Metís, and Dené peoples, are now entirely uninhabitable. ${ }^{24}$ Though members of these First Nations still live in Alberta not far from the site of the tar sands project, the contamination of the land and water has been so bad that they fear drinking the water, hunting game, and planting on the land. Cancer rates have soared in their communities. ${ }^{25}$ The Canadian government has repeatedly denied that the tar sands project is the cause of these issues, insisting that the project provides jobs for members of Indigenous communities, even though prior to beginning extraction, the Indigenous peoples were able to survive and carry on their traditional cultural practices through their relationship with the land and subsistence hunting.

Short demonstrates that the oil-extraction process is genocidal insofar as it damages the

\footnotetext{
${ }^{21}$ Donald A. Grinde and Bruce E. Johansen, Ecocide of Native America: Environmental Destruction of Indian Lands and Peoples (Santa Fe: Clear Light Publishers, 1995), 250.

${ }^{22}$ Short, Redefining Genocide, 6.

${ }^{23}$ Ibid., 9.

${ }^{24}$ Ibid., 169-171.

${ }^{25}$ Ibid., 174.
} 
physical health and wellbeing of the Indigenous peoples who live near this site while inhibiting their ability to carry on their traditional cultural practices by inducing fear and taking over more and more of the land on which they lived. Indigenous scholars like Michelle Jacob of the Yakama Nation agree, noting:

from an Indigenous perspective, the Tar Sands extraction project represents an assault on the earth; the fracking, drilling, extraction, and massive construction of pipelines across Turtle Island, from Alberta to the Gulf Coast, is creating a wasteland. Tribal treaty rights and tribal people's ability to protect their homeland become casualties of war in the settler colonial quest to extract resources for profit in the energy wars. ${ }^{26}$

Environmental devastation of this sort functions like a slow genocide, eroding the health of the people, their sovereignty as a nation, and the land, all of which are integral to their group identity. Because this form of genocide might occur over such a long period of time, it may not always be immediately recognizable as genocide, especially when compared to other genocides like the Holocaust, the Rwandan genocide, or the Bosnian genocide.

In this case study, Short treats ascertainable ecocide as a method of genocide but not equivalent to genocide. In other words, like murder, ecocide may be used as a tool to commit genocide or it might not depend on whether it is aimed at (directly or indirectly) destroying a human group. For Short, environmental devastation is one way of destroying human groups that could potentially fall under two criteria for the UN definition of genocide: causing serious bodily or mental harm to members of the group and deliberately inflicting on the group conditions of life calculated to bring about its physical destruction. Through case studies, Short convincingly demonstrates that ecocide carried out by dominant colonial cultures disproportionately affected and continues to affect Indigenous peoples in a genocidal way. His analysis, one of the few in genocide scholarship that makes an explicit connection between the effects of ecocide and its role in genocide, provides new avenues for thinking about the causes of genocide and how they might be prevented.

However, I argue that ecocide is more than just a method. It is genocide. Furthermore, I claim that ascertainable ecocide is always genocide, even if there are no human groups directly or indirectly targeted for destruction. As I will show, Short's analysis, like the UN definition of genocide, is anthropocentric, relying on human-animal and human-nature binaries. This assumption is especially problematic when thinking about the effects of ecocide on Indigenous peoples and the nonhuman members of their communities. Though Short takes an important step toward applying a new decolonizing lens to the study of genocide, I argue that we need to go further by recognizing that metaphysical assumptions that exist for Westerners like human exceptionalism do not necessarily hold for Indigenous peoples. Ecocide is not just a method, which suggests that destroying the natural world is a tool for destroying a group of human people; rather, ecocide is an act of genocide because it literally eliminates, disfigures, and maims the other-thanhuman members of Indigenous communities. Furthermore, by treating ecocide as a method rather than genocide itself, the anthropocentric bias within genocide studies is reinforced and repeated. For both of these reasons, I draw on Native American philosophies of nonhuman personhood to argue in the next sections that ecocide and genocide should be thought of as the same thing and creating a space for ecocide within the legal definition of genocide is one way to render the legal definition of genocide more just.

\section{Nonhuman Personhood and the Genocide-Ecocide Nexus}

Though Short connects ecocide to the practice of genocide, there are two aspects of his analysis that need further development. First, Short deems ecocide problematic because of its devastating effect on human life but not necessarily because of the harm it wreaks on nonhuman beings and the planet. In this respect, Short relies on and maintains a human-nature dualism that understands ecocide to be more morally problematic because of its effects on humans than its effects on other

${ }^{26}$ Michelle M. Jacob, Indian Pilgrims: Indigenous Journeys of Activism and Healing with Saint Kateri Tekakwitha (Tucson: University of Arizona Press, 2016), 64. 
beings. ${ }^{27}$ For example, in his discussion of fracking, Short states,

indeed, in numerous studies from both countries [the US and Australia], local communities most affected by developments often cite considerable negative impacts on the environment and human health, including groundwater contamination, air pollution, radioactive and toxic waste, water usage, earthquakes, methane migration, and the industrialization of rural landscapes, the cumulative effect of which has led to calls for the United Nations Human Rights Council (HRC) to condemn fracking as a threat to basic human rights, particularly the rights to water and health. Fracking development is fast becoming a human rights issue. ${ }^{28}$

Here Short frames ecocide as a human rights problem-ecocide is bad because it infringes upon human freedom. He does not examine the implications of fracking and other types of resource exploitation practices on the lives of nonhuman beings, even though all of these acts are done at their expense. Implicit in this reading of ecocide and genocide is the notion that nature is passive, waiting to be exploited or preserved at the whims of whatever various groups of humans seem to value it at the time. In this outlook, the land, water, air, plants, and nonhuman animals exist for the sake of human use, and their depletion, overuse, and extinction might be tragic on its own but is only immoral insofar as it puts human life in jeopardy. This approach to ecocide leads to the second problem, which pertains to how Short presents the impact of ecocide on Indigenous peoples.

Short's analysis of the impact of ecocide on Indigenous peoples follows from the logic that nature is a passive recipient of human action. For example, in his assessment of the impact of the tar sands extraction, he writes, "[ $t$ ]he effects on downstream indigenous groups are truly staggering. Their ability to hunt, trap and fish has been severely curtailed and, where it is possible, people are often too fearful of toxins to drink water and eat fish from waterways polluted by the 'externalities' of tar sand production." ${ }^{29}$ Elsewhere he writes,

Indigenous peoples living close to and in the midst of tar and sand deposits have been expressing concern over the lethal impacts that these industrial events have had on their communities for years, with elders citing caustic changes to water quality, meat quality, and to the availability of fish and game. Concern is growing recently as health professionals and community members witness more and more friends and family fall ill with a variety of serious illnesses, and local fish populations are inflicted with ever more severe deformities. ${ }^{30}$

In both quotations, Short notes that tar sands extraction has a detrimental effect on nonhuman creatures, but the language he uses indicates that he is thinking about this harm in terms of its consequences for humans. The extraction process is not mentioned in terms of its harm to deer, elk, and other wildlife but only insofar as it affects the freedom of humans to hunt game and acquire meat. His mention of fish is connected to the human fear of eating them. The changes to water quality, the explosion of illnesses, and the increasing precariousness of life are understood only in terms of human suffering.

To be clear, these issues pose serious problems to the health and wellbeing of the individual members of Indigenous communities and the continuation of their cultures. The continuation of their cultures relies on their ability to live according to traditional practices that are rooted in their connection with particular areas of land and the beings that live there. Short demonstrates that

\footnotetext{
${ }^{27}$ I regard binary and dualism as two different things. A binary or dichotomy designates a difference between two kinds often in such a way that suggests that those two kinds are the only options. Dualism is a binary relationship that is framed by differential power relations. For example, the male-female dualism indicates not only sexual difference between two kinds but also the superiority of one kind over the other-in this case, the male over the female. The human-animal dualism functions similarly in that it suggests that there are either humans or animals and that humans rank higher ontologically, morally, etc. than animals or plants within a given metaphysical framework.

${ }^{28}$ Short, Redefining Genocide, 59.

${ }^{29}$ Ibid., 11.

${ }^{30}$ Ibid., 174 .
} 
he recognizes the importance of this connection, but even though he describes this connection in anthropocentric terms. He states,

[a]s Native author and activist Andrea Smith noted (Smith 2005: 121), 'when Native peoples fight for cultural/spiritual preservation, they are ultimately fighting for the landbase which grounds their spirituality and culture'. That is, the land or 'specific geographical setting' (Churchill 2005: 168) with which many indigenous nations/communities identify themselves fundamentally embodies their 'historical narrative' (Abed 2006: 362) and who they are as peoples; with both their 'practices, rituals, and traditions' (ibid.: 327), and their political and socio-economic cohesion as a group, inextricably bound to the surrounding landscape. Alienation from that landscape, therefore inevitably results in the dissolution of an indigenous people's 'network of practical social relations' (Powell 2007: 538), for they will no longer be able to carry out, develop and preserve their 'cultural heritage and traditions,' or 'pass these traditions on to subsequent generations - thereby rendering them 'socially dead. ${ }^{31}$

In this passage, Short continues to think in terms of a human-nature dualism. According to Short, Indigenous peoples have strong connections to the land on which they live; the land is a site at which "practical social relations" take place, but the land itself is not recognized as a participating member in these relations. In fact, for Short, it is not so much that Indigenous peoples become alienated from land, but from the "landscape," which is defined as a particular place or territory in which (presumably human) activity happens. ${ }^{32}$ But this is not the predominant way in which many Native peoples-especially Native Americans, First Nations, and Maori, among others-identify with land. In fact, if we take into account the metaphysical principles that ground the worldview and practices of many of these cultures, we can see that ecocide is a far more direct and egregious crime for these communities than Short seems to acknowledge. To demonstrate this, I draw on two interrelated metaphysical principles that appear in many Indigenous philosophies. ${ }^{33}$ The first principle, which is expressed through the Lakota phrase mitakuye oyasin (all my relations) holds that everything is related. ${ }^{34}$ The second principle expresses that the universe is alive and must be approached in a personal manner. ${ }^{35}$

According to Muscogee scholar Daniel Wildcat, "[s]tated simply, indigenous means 'to be of a place."'36 However, this does not just refer to the fact that individuals are born in particular places. To be of a place is an active concept that denotes an ongoing relationship that shapes and reshapes the identity of the place and the individuals that inhabit it. Place is not an abstract concept that can simply be pointed to on a map. Place is connected to the land itself, and the land is the ground on which all relationships take place; it is the foundation for relationality, and it is also the foundation for identity. For example, according to the Choctaw and Chickasaw creation stories, the peoples of those nations were created from mud and emerged from the ground, the earth literally giving birth to them. Furthermore, Choctaw and Chickasaw oral traditions point to particular locations

\footnotetext{
${ }^{31}$ Ibid., 160. It should be noted that this is one of just two brief explanations that Short gives about the relationship between Indigenous peoples and the land. Of the four people cited in this passage, only two have identified as Native American, and both of them have been involved in controversies about whether they lied about those identities.

${ }^{32}$ Ibid., 160; Merriam-Webster.com Dictionary, s.v. "Landscape," accessed July 27, https://www.merriam-webster.com/ dictionary/landscape.

${ }^{33}$ There are hundreds of Indigenous nations in what is known today as the US and Canada, and they each have their own philosophies. However, there are certain consistent themes that arise across many of these cultures. The principles I identify here are derived from the work of many Native American and First Nations scholars of different tribal affiliations including Vine Deloria, Jr., Anne Waters, Brian Yazze Burkhardt, Luther Standing Bear, and Robin Wall Kimmerer, among others.

${ }^{34}$ Brian Burkhart. Indigenizing Philosophy through the Land: A Trickster Methodology for Decolonizing Environmental Ethics and Indigenous Futures (East Lansing: Michigan State University Press, 2019), 69.

${ }^{35}$ Phrasing adopted from Vine Deloria, Jr. and Daniel R. Wildcat, Power and Place: Indian Education in America (Colorado: Fulcrum Publishing, 2001), 23.

${ }^{36}$ Deloria and Wildcat, Power and Place, 31.
} 
where this happened, including the mounds in Mississippi and Alabama. ${ }^{37}$ In these stories the land is neither passive nor generic. The land is particular, and it actively participates in the creation of the people, and the people share its substance, making them relatives.

As the land itself is an active participant in relationships, it possesses its own power, energy, and purpose. As Lakota scholar Vine Deloria, Jr. elaborates, in an Indigenous worldview "power and place are dominant concepts - power being the living energy that inhabits and/or composes the universe, and place being the relationship of things to each other." 38 The relationships and identities that spring from the land are not abstract concepts, but are particular and lived. For example, Brian Burkhart, a member of the Cherokee Nation, explains that the phrase "we are all related" is not an abstract, universal platitude about interconnectedness. ${ }^{39}$ It refers to relationships with particular beings. Referencing the film Lakota Wisdom Keepers, Burkhart calls attention to the way that Lakota wisdom-keeper David Swallow, Jr. points to specific trees and the earth right at his feet to explain the concept. ${ }^{40}$ In contrast to Short's description of the relationship between Native peoples and the land, the land is an active, lively participant in the making and sustaining of relationships. As Choctaw scholar Laurelyn Whitt explains, "[t]he land and living entities which make it up are not apart from, but a part of, the people. Nor is 'the environment' something outside of, or surrounding, a people. The relation of belonging is ontologically basic. With inherent possession, agency is sometimes held to be reciprocal-a people belongs to/owns the land, and the land belongs to/owns a people." 41 In other words, in this cosmology the land is a person, not a thing or a resource to be consumed. ${ }^{42}$ Haudenosaunee/Anishinaabe scholar Vanessa Watts reinforces this notion of the land as person when she states that the land not only is in relation to Indigenous peoples but also is literally family: "[o]ur truth, not only Anishnaabe and Haudenosaunee people but in a majority of Indigenous societies, conceives that we (humans) are made from the land; our flesh is literally an extension of the soil." 43

Though Short recognizes that land is not generic and that removing Indigenous peoples from their lands is harmful because they have specific ties to those particular lands, insofar as he is still working from a Western notion of personhood, he misses an important point: "power and place produce personality." ${ }^{44}$ According to Deloria, this means that "the universe is alive, but it also contains within it the very important suggestion that the universe is personal and, therefore, must be approached in a personal manner." ${ }^{45}$ For Indigenous peoples, the problem of dispossession is not just a matter of having land-it is a matter of staying connected to the particular land with which they have relationships and knowledge. As Tewa philosopher Gregory Cajete explains, the relationship between the people and land is so deep and intense that forced removal constitutes a kind of "soul death" for entire generations, resulting in profound homesickness and psychological trauma ${ }^{46}$ If the land is a living being that possesses power, particularity, personality, and agency, then the land is more than just a landscape-it is a member of the community. And as such, actions

\footnotetext{
${ }^{37}$ LaDonna Brown, "The Chickasaw Creation Story," Chickasaw TV Video Network, November 7, 2020, video, 00: 00:1700:00:34, accessed July 26, 2020, https://www.chickasaw.tv/videos/the-chickasaw-creation-story; Ken Carleton, "Nanih Waiya: Mother Mound of the Choctaw," The Delta Endangered 1, no.1 (Spring 1996), accessed July 16, 2020, https://www.nps.gov/archeology/cg/vol1 num1/mother.htm; Richard Green, "Moundville: Home of Prehistoric Chickasaws?" Chickasaw TV Video Network, video, October 9, 2017, 00:00:08-00:00:27, accessed July 26, 2020, https:// www.chickasaw.tv/videos/moundville-home-of-prehistoric-chickasaws.

${ }^{38}$ Deloria and Wildcat, Power and Place, 23.

${ }^{39}$ Brian Burkhart, Indigenizing Philosophy, 69.

${ }^{40}$ Ibid.

${ }^{41}$ Laurelyn Whitt, Science, Colonialism, and Indigenous Peoples: The Cultural Politics of Law and Knowledge (New York: Cambridge University Press, 2009), 43.

${ }^{42}$ Thomas M. Norton-Smith, The Dance of Person and Place: One Interpretation of American Indian Philosophy (Albany: State University of New York Press, 2010), 90.

${ }^{43}$ Vanessa Watts, "Indigenous Place-Thought and Agency Amongst Humans and Non-humans (First Woman and Sky Woman Go on a European World Tour!)," Decolonization: Indigeneity, Education \& Society 2, no. 1 (2013), 27.

${ }^{44}$ Deloria and Wildcat, Power and Place, 23.

${ }^{45}$ Ibid.

${ }^{46}$ Gregory Cajete, Native Science: Natural Laws of Interdependence (Santa Fe: Clear Light Publishers, 2000), 188.
} 
like strip mining, tar sands extraction, fracking, deforestation, and other activities that disfigure the land are more than just ecocidal-they are genocidal. Destruction of the land is not just a means of destroying human group life; to destroy the land is to harm a living member of the community.

A similar argument can be made in regard to other-than-human animals, plants, and other beings that share the land that Indigenous peoples inhabit. According to Shawnee philosopher Thomas Norton-Smith, Native Americans have an expansive notion of personhood, which reflect the insights that "(1) personhood does not constitute the essence of a human being; (2) an entity is a person by virtue of its membership and participation in a network of social and moral relationships and practices with other persons; and (3) moral agency is at the core of personhood." ${ }^{77}$ This view of personhood contrasts sharply with many theories of personhood in the Western worldview, which almost exclusively attribute personhood to humans due to various characteristics that are supposedly unique to human life-primarily rationality, agency, moral reasoning, and free will. ${ }^{48}$ Because the Western notion of personhood relies on human uniqueness, it frequently assumes a hierarchy between humans, animals, and other beings. However, this hierarchy does not exist for many Native American communities. Chickasaw writer Linda Hogan, explains, "[f]or us, the animals are understood to be our equals. They are still our teachers. They are our helpers and healers. They have been our guardians and we have been theirs." 49

Being members of different species is not a barrier to these relationships because underlying this approach to nonhuman personhood is the ontological principle that everything is related. As Deloria explains, "[e]verything in the natural world has relationships with every other thing and the total set of relationships makes up the natural world as we experience it." ${ }^{50}$ Put differently, no human or nonhuman being exists independently; all things are connected to one another in lively, complex relationships. In contrast to the view that nonhuman nature is dead, inert, or passive, from Native American worldviews, nonhuman animals like deer, bears, and salmon, along with bodies of water, features of the land like canyons or buttes, and sacred objects like drums and pipes can all possess a kind of power, force or spirit. Algonkin tribes call it manitou, but other tribes use the terms nilchi'i (Dine), usen (Apache), wakan (Lakota), and orenda (Wendat). ${ }^{51}$ This quality imbues beings with their own animacy, power, and purposiveness, which calls for recognition and respect. The recognition that other beings possess manitou cannot be reduced to religious belief; it is a fact of the world. According to Norton-Smith, spiritual forces like manitou are experientially akin to the Western concept of the mind. In other words, even though one does not have direct access to the thoughts and mental states of others, one can infer from experience that other humans have minds. Likewise, outward signs indicate that other-than-human beings possess manitou. ${ }^{52}$ Because all beings are capable of sharing these attributes and are in relation to one another, there is no passive or isolated being-in-the-world. Everything has the potential to be a person through its relationships and through the obligations it owes and receives.

This notion of personhood has real effects in the world, guiding the form that relationships between humans and other animals take. According to Native American philosophies, humans and other animals are kin. Black Elk of the Oglala Lakota, for example, describes how his life story is "of all life that is holy and is good to tell, and of us two-leggeds sharing in it with the four-leggeds and the wings of the air and all green things; for these are children of one mother and their father is one spirit." ${ }^{53}$ In other words, other-than-human animals and plants are siblings to humans. In many Western societies it is accepted that humans have moral obligations first and foremost to

\footnotetext{
${ }^{47}$ Norton-Smith, Dance of Person and Place, 86.

${ }^{48}$ In some Western nations, like the US, personhood has, strangely, also been attributed to corporations.

${ }^{49}$ Linda Hogan, "First People," in Intimate Nature: The Bond between Women and Animals, ed. Linda Hogan et al. (New York: Fawcett Columbine, 1997), xi.

${ }^{50}$ Vine Deloria Jr., "Relativity, Relatedness, and Reality," in Spirit and Reason: The Vine Deloria, Jr., Reader, ed. Barbara Deloria et al. (Golden: Fulcrum Publishing, 1999), 34.

${ }^{51}$ Viola F. Cordova, "What Is the World?" in How It Is: The Native American Philosophy of V.F. Cordova, ed. Kathleen Dean Moore et al. (Tucson: University of Arizona Press, 2007), 103-4. Norton-Smith, Dance of Person and Place, 86.

${ }^{52}$ Norton-Smith, Dance of Person, 87.

${ }^{53}$ Quoted in Norton-Smith, Dance of Person, 90.
} 
their immediate human kin and family. By understanding relationships with nonhuman persons as familial, Indigenous peoples more easily fold those beings into their realm of moral obligation. What binds people together is not species membership but a shared experience, knowledge, and participation in life that is rooted in a particular place..$^{54}$

These relationships also take more political forms. For instance, First Nations and Native American scholars like Nuu-cha-nuulth philosopher Eugene Richard Atleo, Anishinaabe writer Leanne Betasamosake Simpson, and Cajete say that for many tribes nonhuman animals and humans are in treaty relationships: "[a]ccording to Nishnaabeg traditions, our relationship with the moose nation, the deer nation and the caribou nation is a treaty relationship like any other, and all the parties involved have both rights and responsibilities in terms of maintaining the agreement." ${ }^{55}$ All three authors describe particular protocols ${ }^{56}$ that must be followed when dealing with nonhuman animal nations that demonstrate the proper amount of respect for those beings whose activities and lives sustain Native communities. ${ }^{57}$ For example, Simpson considers a story about the sudden disappearance of the caribou. After searching high and low for any trace of the missing caribou, one seeker sent out from the Nishnaabeg met a young doe who told the seeker that the caribou had left after being disrespected by the Nishnaabeg people. The caribou felt that the people did not appreciate their gifts as evinced by practices of overhunting, wasting meat, and not showing proper reverence. The tribe sent diplomats, spiritual leaders, and mediators to listen to and negotiate with the caribou, and eventually the two parties came to a mutually satisfactory agreement about how the Nishnaabeg should interact with the caribou, resulting in a political treaty. ${ }^{58}$ This story demonstrates that from an Indigenous perspective, other-than-human animal beings are seen as equal to humans. They have their own communities, interests, and politics, and they are recognized as constituting nations themselves.

Accepting either claim about human-nonhuman relationships-that other-than-human animals are kin to humans or that other-than-human animals are political beings that have their own nations - leads to a radical rethinking of who and what is affected by ecocide and genocide. The UN definition of genocide states that genocide involves killing a group in whole or in part. If we accept that nonhuman beings like land, salmon, and maize can be kin to humans, then killing other-than-human persons is a direct attack on a given community or group, and their destruction constitutes destroying part of that "human" group. Likewise, if we accept that a political relationship exists between humans and other-than-human persons, this also amounts to genocide. One of the groups named in the UN definition of genocide is the national group. If groups of nonhuman animals consist of separate nations, their destruction is genocide. ${ }^{59}$ While that genocide may lead to the genocide of the humans who are in relation to nonhuman nations, it can also be recognized independently from the genocide experienced by humans. To illustrate this, consider the mass slaughter of buffalo that was carried out during westward expansion in the US.

In her article "Buffalo Genocide in the Nineteenth Century", Tasha Hubbard of the Cree, Nakota, Anishinaabe, and Metís makes this point exquisitely. She argues that the destruction of the buffalo was genocidal not simply because it led to the physical and social deaths of human persons,

\footnotetext{
${ }^{54}$ Deloria and Wildcat, Power and Place, 32-34.

${ }^{55}$ Leanne Betasamosake Simpson, Dancing on Our Turtle's Back: Stories of Nishnaabeg Re-creation, Resurgence, and a New Emergence (Winnipeg: Arbeiter Ring Publishing, 2011), 111; See also Eugene Richard Atleo (Umeek), Tsawalk A Nuuchah-nulth Worldview (Vancouver: UBC Press, 2004); and Cajete, Native Science.

${ }^{56}$ Simpson prefers to use the word "practice" rather than "protocol" because protocols are rules that substitute for engaged practices of producing relationships. I continue to use the word here, however, because other authors like Atleo use them to denote formal procedures, which is conveyed more clearly through the word "protocol." See Atleo, Tsawalk A Nuu-chah-nulth Worldview, 17, 62.

${ }^{57}$ Atleo, for example, begins Tsawalk by recounting a whale hunt carried out by his grandfather where the protocols were performed incorrectly. The disruption almost caused the hunt to fail, but thanks to the intervention of Wren, who recognized that the proper ceremonies were disrupted accidentally, the hunt was set back on track. See Atleo, Tsawalk A Nuu-chah-nulth Worldview, $\mathrm{x}$.

${ }^{58}$ Leanne Betasamosake Simpson, As We Have Always Done: Indigenous Freedom Through Radical Resistance (Minneapolis: University of Minnesota Press, 2017), 58-61.

${ }^{59}$ Furthermore, claiming that nonhuman animal groups have no nationhood would also be a rejection of the worldview of many Indigenous peoples, contributing to the genocidal erasure of their cultures and ways of life.
} 
but because "specific genocidal practices and their theoretical underpinnings can be applied to the buffalo slaughter." ${ }^{60}$ Citing historical documents, she shows how settlers intentionally set about slaughtering buffalo with the goal of exterminating them, killing vast numbers of them and kidnapping calves, which resulted in the social death of the buffalo and the decline of their mental and emotional health. ${ }^{61}$ Though Hubbard's argument is quite compelling, reviewing the case of the buffalo is worthwhile in order to demonstrate what is at stake.

\section{Buffalo Genocide}

Before 1800, 30 million to 60 million buffalo lived on the plains from Northern Saskatchewan to New Mexico and as far east as the Appalachian Mountains. ${ }^{62}$ Their presence shaped the environment, making them a keystone species. ${ }^{63}$ For the plains tribes, the buffalo were a crucial component of their cultures and social fabric. Not only did the buffalo create a particular habitat suited to a diverse ecosystem in which Indigenous peoples could survive, their bodies provided a source of food, clothing, shelter, and tools. Additionally, the buffalo were central to the spiritual identity of the community. According to Black Elk, "[i]t was the White Buffalo Cow Woman who in the beginning brought to us our most sacred pipe, and from that time, we have been related with the Four-Leggeds and all that moves. Tatanka, the buffalo, is the closest four-legged relative that we have, and they live as a people, as we do." ${ }^{64}$

By the mid-1800s, the buffalo populations were starting to decline.$^{65}$ White settlers, who were bringing their cattle onto the land, displaced the buffalo. Tribes from the east, forced to vacate their traditional homelands, were removed onto plains land, leading to greater demand for the buffalo as a resource. ${ }^{66}$ This process was accompanied by sudden growth in the buffalo hide robe market. In 1835, the American Fur Co. alone had an order for 36,000 buffalo robes, and by 1857, the number of hides delivered to retailers was up to 70,400 hides per year. ${ }^{67}$ Between 1872 and 1873, over 825,000 hides were transported by rail from the plains to the east. ${ }^{68}$ But the real devastation took place during the 1870s and 80s as hunters, the military, and growing numbers of cattle ranchers moved deeper into the plains, eliminating buffalo for their own varied purposes. The expansion of the railroad and cattle ranching into the west occurred simultaneously as part of the industrialization of American agriculture and was bolstered by the Homestead Act of 1862, which granted settlers 160 acres of land each. The destruction of the buffalo herds made more room for ranchers and opened up a new market of beef buyers - the Native Americans who were starving as a result of the depletion of the buffalo herds. ${ }^{69}$

Historian Daniel Smits argues that the military played a significant role in the extermination of the bison. ${ }^{70}$ The army was integral to securing the frontier and pushing it westward, making room for the railroads and accompanying ranchers and settlements. General William T. Sherman, for example, held that getting rid of the buffalo was necessary for the development of the rail system,

\footnotetext{
${ }^{60}$ Tasha Hubbard, "Buffalo Genocide in Nineteenth-Century North America: 'Kill, Skin, and Sell,'”' in Colonial Genocide in Indigenous North America, ed. Andrew Woolford et al. (Durham: Duke University Press, 2014), 295. 
and frequently sponsored civilian hunting expeditions were one solution to the problem. Likewise, in his memoirs, Lieutenant John M. Schofield, commander of the Department of Missouri from 1869-1870, wrote, "[w]ith my cavalry and carbined artillery camped in front, I wanted no other occupation in life than to ward off the savage and kill off his food until there should no longer be an Indian frontier in our beautiful country." ${ }^{11}$ Slaughtering the buffalo had a two-fold benefit. It cleared land for settlers and took care of the so-called "Indian problem." An article in Navy Journal from June 26, 1869 reported that Sherman stated "that the quickest way to compel the Indians to settle down to civilized life was to send ten regiments of soldiers to the plains, with orders to shoot buffaloes until they became too scarce to support the redskins." ${ }^{72}$ For the army, the buffalo and Native Americans were so inextricably linked that soldiers would occasionally pretend that when they were killing buffalo they were actually killing Indians. ${ }^{73}$ The killing of buffalo was a symbolic act that also had real life-threatening consequences for Indigenous peoples and their cultures.

The army worked in tandem with hunters as a method of eradicating Native Americans, often sponsoring hunting expeditions and inviting hunters to accompany them. ${ }^{74}$ Killing the buffalo provided the hunters with sport and profit. With the development of the railroads, amateur hunters took excursions to the plains to shoot buffalo from the train windows as they passed herds. ${ }^{75}$ Their impact on the herds was relatively benign compared to the market hunters, some of whom claimed they could kill forty to fifty buffalo in a day.

[The hunters] often worked in pairs. They would hide in a foxhole and wait for a herd to pass. Killing the herd leader was the most effective way to start. If you could kill the boss, the herd would dissolve into grand confusion, because it would take some time for a new leader to emerge. The next best plan was to kill an animal and wait until others in the herd caught the scent of blood. With the aid of a needle gun and telescopic sight, it was easy to hit one animal. After it had fallen, all those near enough to smell the blood would circle around the fallen one, sniffing the air and pawing the ground. These stationary targets were easy to pick off, one by one. ${ }^{76}$

According to Hubbard, the hunters were not simply taking advantage of the fear and chaos incited within the buffalos but also preying on the complex social and inner lives of the buffalo. She states, "[b]uffalo feel grief for their dead, according to both my traditional teachers and the longtime buffalo warden at the Grasslands National Park, Wes Olson. He has observed [that]...rather than abandon the body, buffalo will stay with the deceased, attempt to revive their family member, and make audible sounds of grief." 77 Not only do buffalo feel grief for their dead, but the killing of adults and kidnapping of young buffalo broke down the buffalo's own social relations and led to mental illness. Hubbard recounts the experiences of John Cook, a buffalo hunter:

[T] he hunters' [had a] practice of surrounding available waterways, forcing the buffalo to approach anyway, and gunning them down. Those buffalo who managed to find a water source that was free from hunters 'would rush and crowd in pell-mell, crowding, jamming, and trampling down both the weak and the strong, to quench a burning thirst. Many of them were rendered insane from their intolerable, unbearable thirst' (Cook 1938: 198). Instead of living cooperatively in their herd society, the buffalo were tortured prior to their death at the hands of the hide hunters. ${ }^{78}$

\footnotetext{
${ }^{71}$ Quoted in Smits, The Frontier Army, 316.

${ }^{72}$ Ibid., 317.

${ }^{73}$ Ibid., 318.

${ }^{74}$ David A. Dary, The Buffalo Book: The Full Saga of the American Animal (Sage Books, 1989).

${ }^{75}$ White, Hunting Buffalo, 46.

${ }^{76}$ Ibid., 49.

${ }^{77}$ Hubbard, Buffalo Genocide, 300.

${ }^{78}$ Ibid.; John R. Cook, The Border and the Buffalo: An Untold Story of the Southwest Plains (Chicago: Lakeside Press, 1938$), 198$.
} 
Hubbard contends that ignoring the personhood of the buffalo reinforces the anthropocentric bias in genocide scholarship, which leads to a failure to account for the types of relationships between humans and other-than-human beings that exist in many Indigenous cultures. ${ }^{79}$ The death of the buffalo had a debilitating effect on the Indigenous communities who regarded them as kin, allies, and protectors. According to environmental activist Winona LaDuke of the Anishinaabe, "[m]any Native people view the historic buffalo slaughter as the time when the buffalo relatives, the older brothers, stood up and took the killing intended for their younger brothers, the Native peoples." 80

\section{Conclusion}

If we accept the veracity of the principles that everything is related ${ }^{81}$ and that the universe is alive and must be approached in a personal manner, then ecocide is not simply a method of genocide. It is genocide. For the Native American scholars discussed above, relationships between humans and other beings are frequently equal and nonhierarchical. Other beings have both personality and power and, as such, must be treated with the same respect accorded to human persons. According to Short, ecocide is genocide when it harms human groups. Destruction of nonhuman nature is problematic because it destroys a resource upon which humans rely for their biological and cultural survival. From a Native American perspective, however, nonhuman nature is not merely a resource-its value does not lie solely in whether it can serve human purposes. Rather, no ethical distinction exists between human groups and the other-than-human beings that are part of those communities. Everything is related; everything is connected. This means that ecocide is personal.

For example, during the 2016-17 Standing Rock movement against the Dakota Access Pipeline, Native American protestors held signs that stated, "Water is sacred" and "Water is life." These posters did more than signify the fear that a resource would be affected. These words signified a concern about the wellbeing, health, and livelihood of the water and land for its own sake as an integral member of the community. As Joyce Rain Anderson explains, thinking of the Native Americans who came to Standing Rock to resist the pipeline project as protesters is inaccurate: "[i]n most Native nations, the people see themselves as caretakers of Mother Earth, enacting that inseparable link between land and body. In other words, we are relatives, and that relationship calls for responsibility." 82 Ojibwa scholar Dennis H. McPherson and philosopher Douglas J. Rabb echo this sentiment in their book Indian from the Inside: "[t]here is, we suggest, a moral obligation to protect the habitat of the moose, the beaver, the muskrat, and the lynx; the habitat of geese, ducks, grouse and hare, not just because members of the Band wish to continue hunting and trapping, but because these other-than-human persons are also extended members of the Ojibwa society." 83

To adequately address the harms suffered by Native Americans and other Indigenous groups as a result of ecocide, the definition of genocide needs to change so that it does not exhibit an anthropocentric bias that limits potential victims of genocide to human groups. Further grounds for such a change could also be established by reversing the claim that ecocide is genocide to genocide is ecocide. Although digging deeply into this line of argumentation is beyond the scope of this article, there is already research that demonstrates how humans are participants in ecosystems that become disturbed when humans are removed from them or when the human groups occupying those localities change ${ }^{84}$ To briefly elaborate on this point, consider William Cronon's research

${ }^{79}$ Ibid., 295.

${ }^{80}$ LaDuke, All Our Relations, 154.

${ }^{81}$ Raymond Pierotti, Indigenous Knowledge, Ecology and Evolutionary Biology (New York: Routledge, Taylor and Francis Group, 2011)

${ }^{82}$ Joyce Rain Anderson, “Walking with Relatives: Indigenous Bodies of Protest," in Unruly Rhetorics: Protest, Persuasion, and Publics, ed. Jonathan Alexander et al. (Pittsburgh: University of Pittsburg Press, 2018), 48.

${ }^{83}$ Dennis H. McPhereson and Douglas J. Rabb, Indian from the Inside: Native American Philosophy and Cultural Renewal, 2nd ed. (Jefferson: McFarland \& Co., Inc., 2011), 91.

${ }^{84}$ Russel. L. Barsh, “Forests, Indigenous Peoples, and Biodiversity,” Global Biodiversity 7, no. 2 (1997), 20-24; Henry T. Lewis, "A Parable of Fire: Hunter Gatherers in Canada and Australia," in Traditional Ecological Knowledge: A Collection of Essays, ed. Robert E. Johannes, (Cambridge. IUCN, 1989); Roderick Neuman, Imposing Wilderness: Struggles over Livelihood and Nature Preservation in Africa (Los Angeles: University of California Press, 1998); Raymond Pierotti and 
in his book Changes in the Land. ${ }^{85}$ He documents how the ecology of New England changed upon the arrival of European colonists and the displacement of Native Americans from their lands. For example, various tribes in the northeastern US practiced forest management techniques including controlled burning. Such practices allowed certain trees, including birch, pitch pine, and white pine, that grow well in direct sunlight to flourish while keeping underbrush at bay ${ }^{86}$ Doing so provided open pathways through the woods that allowed larger game animals like deer and lowlying plants like strawberries to proliferate. As Native peoples were displaced from their lands and encouraged to adopt European lifestyles, these practices came to an end, which ultimately changed which species were able to thrive and survive. Regardless of whether some species were seen as desirable for extraction and consumption by the settlers, the simple change in how humans were or were no longer interacting with the land would have led some species to experience dramatic changes to their survivability and to suffer great losses of life, making the removal of Indigenous people from the land a form of ecocide.

In contemporary times, Indigenous peoples have come into conflict with global conservation movements, which care deeply about the health of ecosystems and animal populations but frequently hold the view that such ecosystems flourish best when humans leave them alone. As Mark Dowie illustrates in Conservation Refugees, some Native peoples have not only been forced to discontinue traditional subsistence hunting practices but have even been displaced from their lands so that the land and its other-than-human inhabitants can be protected. ${ }^{87}$ Certain attitudes about conservation, made explicit in documents like the U.S. Wilderness Act of 1964, which states that wilderness is "an area where the earth and its community of life are untrammeled by man, where man himself is a visitor who does not remain," 88 demonstrate a strong human-nature binary that appears to reject the notion that humans can have a non-destructive function within an ecosystem. Views like this are used to justify forced relocations of Indigenous peoples, which in turn interfere with the cultural traditions of those human groups; such interference ultimately may be genocidal based on Lemkin's definition. When these views lead to the displacement of Indigenous groups, they also disrupt and destroy the relationships between humans, the land, and the land's other inhabitants such that those other creatures might face destruction or great losses to their communities and changes to their habitats.

For the most part, Western cultures have largely accepted that humans are ontologically and morally superior to other beings - that humans deserve moral treatment because of their inherent dignity and rights. This view has been at the expense of other-than-human beings and does not reflect the ontology of non-Western worldviews, such as the Indigenous philosophies described above. Ideally, the definition of genocide should be rewritten to incorporate nonhuman groups as groups that can be targeted through genocide. Until the definition of genocide is altered, the definition will continue to reflect a colonial worldview that has been used to excuse the destruction of nonhuman nature and oppress Native peoples. However, since ratification of such a change is highly unlikely given the current state of the world and the entrenched views about human-animal relations, at minimum, ecocide needs to be recognized as an act of genocide. This addition would not only help capture some cultural components lost in the transition from Lemkin's definition to the UN's but also mitigate some of the anthropocentric and Western biases of the UN definition and provide Indigenous peoples and other groups with more leverage for contesting climate change and other devastating acts against nonhuman nature.

Daniel Wildcat, "Traditional Ecological Knowledge: The Third Alternative (Commentary)," Ecological Applications 10, no. 5 (October 2000), 1333-1340.

${ }^{85}$ William Cronon, Changes in the Land: Indians, Colonists, and the Ecology of New England (New York: Hill and Wang, 2003).

${ }^{86}$ Cronon, Changes in the Land, 30.

${ }^{87}$ Mark Dowie, Conservation Refugees: The Hundred-Year Conflict between Global Conservation and Native Peoples (Cambridge: MIT Press, 2009).

${ }^{88}$ The Wilderness Act, 16 U.S.C. 1131-1136 (1946), accessed July 30, 2020 https://www.nps.gov/orgs/1981/upload/WAct 508.pdf 


\section{Acknowledgements}

As a non-Indigenous person of European descent who wrote this article while living on the traditional lands of the Kalapuya and Chesapeke peoples, I would like to express my gratitude to the Indigenous scholars and communities who have shared their philosophies and stories, which has made this critique possible. I hope this research contributes to creating a more equitable pathway for Indigenous peoples to achieve justice for the violence they have experienced and are experiencing. I would also like to thank the editors for their support and the reviewers for their thoughtful feedback on this article.

\section{Bibliography}

Alvarez, Alex. Native America and the Question of Genocide. Lanham: Rowman \& Littlefield, 2014.

Anderson, Joyce Rain. "Walking with Relatives: Indigenous Bodies of Protest." In Unruly Rhetorics: Protest, Persuasion, and Publics. Edited by Jonathan Alexander, Susan C. Jarrett, and Nancy Welch, 45-59. Pittsburgh: University of Pittsburg Press, 2018. Doi: 10.2307/j.ctv75d8pr.6

Atleo, Eugene Richard (Umeek). Tsawalk: A Nuu-chah-nulth Worldview. Vancouver: UBC Press, 2004.

Barsh, Russel. L. "Forests, Indigenous Peoples, and Biodiversity." Global Biodiversity 7, no. 2 (1997), 20-24.

Brown, LaDonna. “The Chickasaw Creation Story.” Chickasaw TV Video Network. November 7, 2013. Video, 00:01:37. Accessed July 26, 2020. https://www.chickasaw.tv/videos/the-chickasawcreation-story.

Burkhart, Brian. Indigenizing Philosophy through the Land: A Trickster Methodology for Decolonizing Environmental Ethics and Indigenous Futures. East Lansing: Michigan State University Press, 2019. Doi: $10.14321 / j . c t v k j b 3 x p$

Cajete, Gregory. Native Science: Natural Laws of Interdependence. Sante Fe: Clear Light Publishers, 2000.

Card, Claudia. "Genocide and Social Death." In Genocide's Aftermath: Responsibility and Repair. Edited by Claudia Card and Armen T. Marsoobian, 10-26. Malden: Blackwell Publishing, 2007.

Carleton, Ken. "Nanih Waiya: Mother Mound of the Choctaw," The Delta Endangered 1, no.1 (Spring 1996). Accessed July 16, 2020. https://www.nps.gov/archeology/cg/vol1 num1/mother. htm.

Cook, John R. The Border and the Buffalo: An Untold Story of the Southwest Plains. Chicago: Lakeside Press, 1938.

Cordova, Viola F. "What Is the World?.” In How It Is: The Native American Philosophy of V.F. Cordova. Edited by Kathleen Dean Moore, Kurt Peters, Ted Jojola, and Amber Lacy, 100-106. Tucson: University of Arizona Press, 2007.

Cronon, William. Changes in the Land: Indians, Colonists, and the Ecology of New England. New York: Hill and Wang, 2003.

Dary, David A. The Buffalo Book: The Full Saga of the American Animal. Sage Books, 1989.

Deloria Jr., Vine. "Relativity, Relatedness, and Reality." In Spirit and Reason: The Vine Deloria, Jr., Reader. Edited by Barbara Deloria, Kristen Foehner, and Sam Scinta, 31-39. Golden: Fulcrum Publishing, 1999.

Deloria Jr., Vine and Daniel R. Wildcat. Power and Place: Indian Education in America. Colorado: Fulcrum Publishing, 2001.

Dowie, Mark. Conservation Refugees: The Hundred-Year Conflict between Global Conservation and Native Peoples. Cambridge: MIT Press, 2009. Doi: 10.7551/mitpress/7532.001.0001

Fitzgerald, David and Linda Hasselstrom. Bison: Monarch of the Plains. Portland: Graphic Arts Center Publishing Company, 1998.

Gone, Joseph P. "Colonial Genocide and Historical Trauma in Native North America: Complicating Contemporary Attributions." In Colonial Genocide in Indigenous North America. Edited by Andrew Woolford, Jeff Benvenuto, and Alexander Laban Hinton, 273-291. Durham: Duke University Press, 2014. Doi: 10.1215/9780822376149-013

Green, Richard. "Moundville: Home of Prehistoric Chickasaws?" Chickasaw TV Video Network, October 9, 2017. Video, 00:01:22. Accessed July 26, 2020. https://www.chickasaw.tv/videos/ moundville-home-of-prehistoric-chickasaws.

Grinde, Donald A. and Bruce E. Johansen. Ecocide of Native America: Environmental Destruction of Indian Lands and Peoples. Santa Fe: Clear Light Publishers, 1995. 
Hämäläinin, Pekka. "The First Phase of Destruction: Killing the Southern Plains Buffalo, 17901840." Great Plains Quarterly 21, no. 2 (April 1, 2001), 101-114.

Higgins, Polly. Eradicating Genocide: Laws and Governance to Prevent the Destruction of Our Planet. London: Shepheard-Walwyn LTD, 2010.

Hogan, Linda. "First People." In Intimate Nature: The Bond between Women and Animals. Edited by Linda Hogan, Deena Metzger, and Brenda Paterson, 6-19. New York: Fawcett Columbine, 1997.

Hubbard, Tasha. "Buffalo Genocide in Nineteenth-Century North America: 'Kill, Skin, and Sell."' In Colonial Genocide in Indigenous North America. Edited by Andrew Woolford, Jeff Benvenuto, and Alexander Laban Hinton, 292-305. Durham: Duke University Press, 2014. Doi: $10.1215 / 9780822376149-014$

Isenberg, Andrew C. The Destruction of the Bison: An Environmental History, 1750-1920. New York: Cambridge University Press, 2000. Doi: 10.1017/CBO9780511549861

Jacob, Michelle M. Indian Pilgrims: Indigenous Journeys of Activism and Healing with Saint Kateri Tekakwitha. Tuscon: University of Arizona Press, 2016.

LaDuke, Winona. All Our Relations: Native Struggles for Land and Life. Massachusetts: South End Press, 1999.

Lemkin, Raphaël. Axis Rule in Occupied Europe. New Hampshire: Rumford Press, 1944.

Lewis, Henry T. "A Parable of Fire: Hunter Gatherers in Canada and Australia." In Traditional Ecological Knowledge: A Collection of Essays. Edited by Robert. E. Johannes, 7-20. Cambridge: ICUN, 1989.

McPhereson, Dennis H. and Douglas J. Rabb. Indian from the Inside: Native American Philosophy and Cultural Renewal. $2^{\text {nd }}$ ed. Jefferson: McFarland \& Co., Inc., 2011.

Moses, Dirk A. "Empire, Colony, Genocide: Keywords and the Philosophy of History." In Empire, Colony, Genocide: Conquest, Occupation, and Subaltern Resistance in World History. Edited by A. Dirk Moses, 3-54. New York: Berghan Books, 2008.

Merriam-Webster.com Dictionary, s.v. "Landscape." Accessed July 27, 2020. https://www.merriamwebster.com/dictionary/landscape.

Neuman, Roderick. Imposing Wilderness: Struggles over Livelihood and Nature Preservation in Africa. Los Angeles: University of California Press, 1998.

Norton-Smith, Thomas M. The Dance of Person \& Place: One Interpretation of American Indian Philosophy. Albany: State University of New York Press, 2010.

Pierotti, Raymond. Indigenous Knowledge, Ecology and Evolutionary Biology. New York: Routledge, Taylor and Francis Group, 2011. Doi: 10.4324/9780203847114

Pierotti, Raymond and Daniel Wildcat. "Traditional Ecological Knowledge: The Third Alternative (Commentary)." Ecological Applications 10, no. 5 (October 2000), 1333-1340. Doi: 10.1890/1051-0761(2000)010[1333:TEKTTA]2.0.CO;2

Short, Damien. Redefining Genocide: Settler Colonialism, Social Death, and Ecocide. London: Zed Books, 2016.

Simpson, Leanne Betasamosake. Dancing on Our Turtle's Back: Stories of Nishnaabeg Re-creation, Resurgence, and a New Emergence. Winnipeg: Arbeiter Ring Publishing, 2011.

---------. As We Have Always Done: Indigenous Freedom Through Radical Resistance. Minneapolis: University of Minnesota Press, 2017.

Smits, David D. "The Frontier Army and the Destruction of the Buffalo: 1865-1883." Western Historical Quarterly 25, no. 3 (Autumn 1994), 312-338. Doi: $10.2307 / 971110$

United Nations. General Assembly resolution 260, Convention on the Prevention and Punishment of the Crime of Genocide. December 9, 1948. UN Doc. A/RES/260(III). Accessed April 24, 2019. https://www.un.org/en/genocideprevention/documents/atrocity-crimes/Doc.1 Convention $\% 20$ on $\% 20$ the $\% 20$ Prevention $\% 20$ and $\% 20$ Punishment $\% 20$ of $\% 20$ the $\% 20$ Crime\%20of\%20Genocide.pdf

Watts, Vanessa. "Indigenous Place-Thought and Agency Amongst Humans and Non-humans (First Woman and Sky Woman Go on a European World Tour!)." Decolonization: Indigeneity, Education \& Society 2, no. 1 (2013), 20-34.

Wilderness Act, 16 U.S.C. 1131-1136 (1946), accessed July 30, 2020 https://www.nps.gov/orgs/1981/ upload/W-Act 508.pdf

White, John H. "Hunting Buffalo from the Train: Buffalo, Iron Horses, and the Path toward Extinction." Railroad History 201 (Fall-Winter 2009), 42-49. 
Whitt, Laurelyn. Science, Colonialism, and Indigenous Peoples: The Cultural Politics of Law and Knowledge. New York: Cambridge University Press, 2009. Doi: 10.1017/CBO9780511760068

Zimmerer, Jürgen. "Colonialism and the Holocaust: Towards an Archaeology of Genocide." Genocide and Settler Society: Frontier Violence and Stolen Indigenous Children in Australian History. Edited by A. Dirk Moses, 49-76. New York: Berghahn Books, 2004. 